\title{
Statistical Codicology. Principles, Directions, Perspectives
}

In an extended, content rich 'overview of twenty years of research', added as an afterword to an equally voluminous collection of reprinted contributions in French and Italian, Ezio Ornato, at the end of the last millennium, carried out a critical retracing of the basic steps involved in a novel approach to the study of the Latin (and Greek) medieval book-an approach that was successfully termed 'quantitative codicology' (also known as 'statistical codicology' or 'experimental codicology'). ${ }^{1}$ The origin, prerequisites, areas of application and principal results of this particular way of addressing the history of the book-both manuscript and printed-are amply and meticulously described in the aforementioned essay; here it should therefore suffice to provide a brief outline of the main principles:

1. The basic rationale underlying the 'quantitative' approach is a conceptualisation of the book as a 'device that functions in a complex way' ('machine au fonctionnement complexe'), ${ }^{2}$ which is to say a handcrafted object designed to transmit a text in the most enduring and legible way, whilst at the same time serving as an expression of a specific 'cultural and social fabric', as well as being the material product of a complex interaction between factors lying within the artisanal sphere (e.g. level of technology, labour ergonomics, the need to economise on materials and production times, etc.) and external factors (e.g. political, historical-social and cultural influences, etc.).

2. This fundamental premise gives rise to the need to study the book-object as a comprehensive whole-a global entity composed of multiple interactions between all of its basic characteristics (e.g. constituent materials and structure, script, images, annotations, content, etc.); all aspects of its genesis and subsequent development (e.g. planning, production, dissemination, uses, transmission, storage and, perhaps, eventual destruction); and

\footnotetext{
1 Ornato 1997. In addition to the cited essay and the collection in which it appears, the reader should also refer to its bibliography (that of the current contribution being limited to essential references), and most recently also to Ornato 2020.
}

2 Bozzolo et al. 1989.

ə Open Access. ( 2022 Marilena Maniaci, published by De Gruyter. (c) BY-Nc-ND This work is licensed under the Creative Commons Attribution-NonCommercial-NoDerivatives 4.0 International License. https://doi.org/10.1515/9783110743838-001 
finally, all the actors involved in that history (e.g. authors, copyists, illuminators, binders, printers, commissioning patrons, readers, etc.).

3. From this scenario arises the necessity to adopt a specific methodology that entails the systematic investigation of entire populations of volumes or statistically significant samples of 'normal' codices ('foule anonyme de manuscrits'), ${ }^{3}$ rather than the learned study of individual books as unique objects, exceptional for their rarity, importance and beauty. This approach-which demands a radical change of perspective, from the 'history of books' to the 'history of the book'-compels one to conduct systematic surveys of large groups of variables, and then to subject the resulting data to multidimensional statistical investigation techniques. For this purpose, it is necessary to break down complex information into simple elements, and then to codify them into measurements (in the case of dimensional parameters, for example), counts (e.g. the number of leaves or quires, the number of holes in the parchment, the number of lines, characters or abbreviations, and so forth), and observations made on the basis of qualitative considerations (e.g. the quality of parchment or decorations, etc.). ${ }^{4}$

4. From the 'quantitative' standpoint, interest is focused on repetitive and routine information (rather than on exceptional and unique features), which has to undergo experimental analysis of a functional kind. The statistics are not used, in a purely descriptive way, to illustrate the propensity of single variables or phenomena, but rather as a means to highlight the book's operating mechanisms (i.e. overall phenomena and long term trends) set up in its structures and general evolutionary lines by factors which are both internal and extraneous to the artisanal world (e.g. technological, functional, cultural, social and economic), and to attempt to explain the genesis and consequences of the same. ${ }^{5}$

5. Given that the essential aims of the book-the transmission of readable content and the fulfilment of specific needs vis-à-vis social and cultural representativeness-and the tensions it is subject to are common to products that differ in terms of technology, form and book tradition, the statistical approach breaks down the barriers that separate the study of manuscript volumes from that of printed books, and the study of codices from

3 Bozzolo / Ornato 1980, 9.

4 On the composition of the relevant samples and the selection and survey methods applied to the investigation parameters, see Maniaci / Ornato 1993a.

5 On the 'experimental' and 'exploratory' nature of the investigative techniques and data interpretation, see Maniaci / Ornato 1993b. 
that of other forms of book, and can be applied, taking into account the specific characteristics of different contexts, to objects belonging to a wide range of 'book cultures'.

From the 1970s onwards, these preconceptions gave rise to a (methodologically speaking) highly cohesive research strand, albeit one that fanned out into a wide range of themes, in addition to being characterised by a progressive enrichment and refinement of selection, surveying and data analysis techniques. Notwithstanding a belief that the statistical approach finds in the history of the manuscript and printed book almost unlimited potential for its application, quantitative research has favoured several areas in which the variables to be surveyed and analysed are easier to identify and to manage; ${ }^{6}$ these are:

1. The study of production trends and of the book market (manuscript and printed volumes), based on a perusal of surviving books, or on a census of indirect sources (e.g. catalogues and registers/inventories).

2. The study of writing materials (e.g. parchment and, above all, paper).

3. The analysis of manuscript and incunabula production techniques.

4. The study of the construction and utilisation of the page, only seemingly ascribable to matters of taste, but which in reality are the result of an interaction, often conflictual, between functional needs (e.g. legibility) and economic requirements (e.g. exploitation of the available space).

5. With respect to the writing, an exploration of 'perigraphic' factors (e.g. subdivision of the text into chapters and paragraphs, separation of words, abbreviations, line management, punctuation, and so forth) and their correlation to the 'decipherability' of the text, taking into account the readers' proficiency.

In contrast to codicology, palaeography has remained (and still remains) at the fringes of the field of statistical analysis, due to the difficulty of translating the characteristics of handwriting into relevant quantitative variables (the definition of an individual letter requires the selection, surveying and evaluation of a large number of parameters), and on account of strong ideological resistance stemming from the presumed 'reduction' of a manifestation of the human spirit to a mere sequence of numbers and tallies. ${ }^{7}$ Some initial attempts-an example of which is

6 For copious examples of the same, the reader is directed to the chapters by [Ornato et al.] 1997 and to the aforementioned afterword by Ornato 1997.

7 Opposition that reasserts itself, in an equally unreserved way, with respect to manifestations of so-called 'digital palaeography', regardless of its relative merit and the results it yields. 
provided in this volume-offer a glimpse of the potential that systematic analysis holds not only for the study of the evolution of individual characters and their interaction with the surface upon which they are written, but also of the operating mechanisms of the graphical system and of the variables which they are subject to (e.g. the sharpness of the pen and the way in which it was held, the position of the leaf, and the gesture described in space by the scribe, of which the visible trace left by the pen constitutes only a partial representation). ${ }^{8}$

After the almost fifty years which have passed since the first application of statistical analysis in the field of codicology, what, then, inspires the publication, in English translation, of a collection of contributions that have already appeared in other settings over the last twenty years or so?

An important reason is the desire to call to the attention of a wider audience on a research strand whose results, which have been published in French and Italian in the main, have polarised the scientific community, eliciting, on the one hand, clear recognition and enthusiasm for their innovativeness, and on the other, equally sharp criticism. ${ }^{9}$ At a time when digital media are increasingly embraced in the sphere of the humanities (encompassing a broad range of applications is only approximately covered by the blanket term 'digital humanities'), quantitative codicology deserves to be recognised for its pioneering role, not only in relation to its innovativeness as an approach to the history of the book, but also for the way in which it favours collegial work (often the result of team work in the form of collaboration between established scholars and neophyte researchers), and for the great potential it holds for the sharing of corpora of data gathered

8 Muzerelle 1999. See also, on the same topic, Muzerelle 2013. In addition, see the pioneering critical analysis by Ornato 1975 on the use of the 'modular ratio' by Gilissen 1973 as a key criterion for distinguishing between copyists.

9 Not by chance, the sharpest criticism has come from scholars of recognised calibre, albeit ones who have little or no expertise in mathematical procedures and digital technology. See, for example, the harsh assessment of Radiciotti 1999, which accuses statistical codicology of oversimplification ('reducing matters to true/false binary logic', 62), or of ambitiously positioning itself ('In this sense, counting for a humanist [and even more so for a historian or a palaeographer] is a way of placing themselves on the "winning" evolutionary trajectory, and hence of identifying themselves as being part of a wider intellectual community, along with other scientists, thereby avoiding isolation, and at the same time gaining social currency [...]', 6970). See also the reservations expressed by Agati 2017. 
during individual investigations, and subsequently made freely available and used for successive research projects.

Over the past twenty years, research on the manuscript book-not solely in relation to the better-known codex format-has greatly broadened its horizons by drawing on methods developed for the practice of Greco-Latin codicology, with the objective of fostering a more systematic and scientifically advanced knowledge of the book cultures established around the Mediterranean basin and in neighbouring regions (e.g. Arabian, Jewish, Syrian, Coptic, Ethiopian, Armenian, Slavic, and Georgian), ${ }^{10}$ and more recently also of the book traditions found in more distant regions of Asia and Africa (involving not only the study of paper, but also of wood, bamboo, palm leaves, tree bark and silk as writing supports). ${ }^{11}$ This all-inclusive and comparative interest in manuscript culture in all its historicalgeographical manifestations provides the opportunity to apply statistical analysis to an almost unlimited range of prospective research. Notwithstanding the advances already made and the work still in progress, in the majority of cases (with the important exception of the Hebrew codex $)^{12}$ the available knowledge only concerns single books or groups of books and suffers from a lack of broad overviews-which only the adoption of statistical analysis as a working method would make possible - upon whose backgrounds one could evaluate the results of specific observations, and by means of which progress could be made in understanding the underlying logic of individual traditions and in interpreting the similarities and differences between them. The openness to a wide range of book forms makes it possible to ascertain whether or not and to what extent the same investigation protocols devised for the codex might be applied to each of them, and at the same time encourages experimentation with certain analysis protocols and new ways of examining data.

It seems reasonable to suppose that the application of statistical analysis to the study of ancient manuscript and printed books-which in the meantime has continued to follow its traditional path-could gain new momentum from the opening up of new areas, which up until now have remained unexplored. The es-

10 See the recent summary of results and orientation provided by Bausi et al. 2015.

11 An awareness of the activities of the Centre for the Study of Manuscript Cultures at the University of Hamburg and the related Sonderforschungsbereich 950 'Manuscript Cultures in Asia, Africa and Europe', along with the Cluster of Excellence 'Understanding Written Artefacts. Material, Interaction, and Transmission in Manuscript Cultures', is indispensable.

12 Thanks to Malachi Beit-Arié's more than fifty years of strong commitment, Hebrew codicology enjoys in Sfardata (http://sfardata.nli.org.il) an incomparable body of documentation based on an in-depth critical examination of all the dated Hebrew manuscripts that bear the names of their scribes. 
sential prerequisite for any such endeavour is the availability of quantitatively and qualitatively representative corpora of data, which for most book traditions remain a distant objective, whether with regard to the building of databases resulting from a close examination of manuscripts, or on account of the lack of availability of detailed scientific catalogues from which second-hand information can be drawn. In a world where science is moving, not unhindered, towards interoperability and data sharing for the purposes of research, it becomes ever more necessary to give thought to surveying protocols and ways of codifying variables shared by manuscripts, and to creating synergy between projects that are pursuing similar ends, and likewise to setting up research trajectories that encompass several traditions (focused, for example, on specific materials or literary content, or on single aspects of the history of materials or book manufacturing techniques). When scrutinising the composition of open collections of data that can be freely used for research of various kinds-in a working environment which increasingly tends towards comparative studies-one has to ask whether, and to what extent, the ever-greater availability of digital data (e.g. descriptions, reproductions and transcriptions) might contribute to the creation of corpora useful for the statistical investigation and serial analysis of their characteristics. At the present time, whilst there is a growing offer of digital catalogues that can freely be made use of online and the possibility of remotely accessing full manuscript digitisations has made locating specific data much easier than before for the scholar, the serial exploitation of these resources is hindered by the impossibility of directly accessing the underlying databases, which can only be consulted by means of the templates provided by those responsible for individual projects. Similarly, the personal use of images, even when they can be freely downloaded, is impeded by the lack of universally shared standards for the capture and codification of digital reproductions. $^{13}$

Methodological and technological problems aside, one has to wonder how statistical codicology will be able to find its place in the sphere of 'digital humanities'. At present, the automation of techniques for the extraction of parameters from images and digital descriptions-which for certain kinds of research certainly represents an advance vis-à-vis the manual execution of measurements and counts-still does not equate to the emergence of genuinely original heuristic prospects, apart from some interesting progress that has been made with respect to ways of gathering, codifying and representing data. ${ }^{14}$

13 For clear-headed criticism of the current limitations of cataloguing and digitisation initiatives, see Ornato 2012b.

14 Even in its most ambitious and well-developed manifestations, 'digital codicology' has mostly concentrated on the realisation of applications aimed at simplifying and rendering more objective 
The present collection of essays is aimed at fulfilling several goals:

- In the first place, to assemble and offer in English translation-so as to facilitate wider accessibility-a selection of contributions which have appeared over the last twenty years or so, in order to take stock of the current 'state of the art', thereby providing the most varied and multi-faceted picture possible of recent advances in quantitative codicology, with respect to the various aspects of manuscript book production and use. ${ }^{15}$

- Then to propose further potential applications of the statistical approachin a synergetic relationship and not in conflict with other methods and research strands-to traditions for which the currently available data are quantitatively and qualitatively very uneven, and about which there is still a lack of general knowledge-even rudimentary-with respect to their corresponding book heritages and the principles underlying their production.

- And finally, to favour the comparison of the preferences and technical solutions devised in different contexts, albeit ones that broadly speaking share the same basic needs, which in various ways conform to a sort of 'universal grammar' ${ }^{16}$ whose rules could become easier to understand if studied from a comparative standpoint.

\footnotetext{
the work of traditional (i.e., analogue) scholars. For a broad overview, see Stokes 2015; for a specific case study see, most recently, Stokes / Noël 2019. On a recent project dedicated to the automatic analysis of the mise en page, see Busch / Chandna 2017, and above all Krause / Hegel 2018, in which a thorough synthesis of the history and objectives of quantitative codicology follows an attempt to identify the basic principles underlying a new theoretical perspective, where the statistical analysis of codicological parameters gleaned from catalogues or acquired first-hand is placed side-by-side with a 'visual analysis' of digital reproductions. On the current potential and limitations of 'digital palaeography', see, for example, Maniaci et al. 2011 and Hassner et al. 2013.

15 On account of limited space, the contributions exclusively dedicated to printed books were not taken into consideration (with the single exception of Ornato 2004, whose focus is on dating documents through watermarks); among these Coq / Ornato 1987, Coq / Ornato 1988 and, more recently, Ornato 2010a, and Albiero 2013 are worth mentioning. See also the monograph by Hermand / Ornato / Ruzzier 2012, which contains a lengthy contribution by Ornato 2012 dedicated to the methodology applicable to the quantitative study of incunabula.

16 The notion of a 'universal grammar of the codex book' has on several occasions been brought up and theorised by Malachi Beit-Arié (here it will suffice to cite Beit-Arié 1993, 5).
} 
For various reasons, the task of selecting the essays to be included in the present compilation proved to be a less than easy one and entailed a certain amount of deliberation and rethinking. In the first place, the application of statistical methods to manuscript history is borne witness to by a significant number of scientific papers that fall into the category of 'quantitative codicology', most of which are long or very long contributions, and sometimes of remarkable complexity. In the wake of the works ascribable to the rather fertile period ushered in by Carla Bozzolo and Ezio Ornato, and further built on by the works of the Quanticod ${ }^{17}$ group, younger scholars have produced some new and interesting results. ${ }^{18}$

Thanks to the achievements of almost fifty years of research, 'quantitative codicology' has in fact become a well-established approach, whether with regard to epistemological presuppositions (the book viewed as the product of a compromise between certain requirements and conditioning of various kinds), or the techniques employed. Such techniques are chiefly those associated with classical statistical analysis, and are based on the subdivision of a corpus according to a number of variables held to be hypothetically relevant, identifying the ones that are correlated and studying in greater depth the observed relationships. ${ }^{19}$ On the other hand, the richness and relative homogeneity of this research strand, the role played by a number of leading figures, and the use of a strongly characterised and familiar argumentative structure and language ${ }^{20}$ have tended to mo-

17 Quanticod - CNRS 1985.

18 In the current setting, it is not possible to provide details of the bibliography relating to all the research themes addressed, which include (the following are intended purely as examples and by no means represent an exhaustive list): writing materials, i.e. parchment (Marilena Maniaci) and paper (Paola Munafò and Maria Speranza Storace, in conjunction with Ezio Ornato); the thickness and composition of quires (Paola Busonero and Marilena Maniaci); the structure of miscellaneous codices (Octave Julien); the mise en page of Greek and Latin volumes, with particular attention to glossed codices (Marilena Maniaci and Luciana Devoti); the characterisation of volumes of specific content, such as the Bible (Marilena Maniaci, Chiara Ruzzier) or liturgical codices (Laura Albiero); the working principles of graphic systems in the Late Middle Ages (Maria Gurrado); the statutes governing medieval copyists in the French context and the reconstruction of the copying process (Émilie Cottereau-Gabillet); and the composition of medieval French and Italian private libraries (Annie Tournieroux). For one of the most unusual applications of statistical analysis to book traditions other than Greek and Latin, see, for example, the work carried out by Arianna D'Ottone Rambach on Yemeni codices (D'Ottone 2006).

19 See Maniaci / Ornato 1993a and 1993b. Somewhat less represented are clustering techniques and factorial analysis, experimented with above all by Denis Muzerelle (see, for example, Bianchi et al. 1993 and Muzerelle 2012).

20 In addition to concepts and tools foreign to the usual formation of scholars, the adoption of a highly technical and not very pedagogical expository style is one of the reasons that have 
nopolise the quantitative ground, resulting in a rather negative effect on the visibility of some other interesting approaches that have developed independently: we have therefore sought provide some space for them in this collection.

The selection of the twenty essays included in the volume was based on the following elemental criteria:

- Coverage of a wide range of themes, including the characterisation of individual book typologies; the study of techniques and manufacturing materials (e.g. quiring, ruling, codex structure, etc.); the layout and utilisation of the page; and even various matters appertaining to the working conditions and methods adopted by medieval copyists.

- Documentation (alongside the most represented branch of the works that spearhead 'quantitative codicology' in the French and Italian tradition) of some other approaches which have developed independently; sometimes of striking originality.

- Exemplification of topics and analytical strategies applicable to manuscript volumes belonging to traditions other than the Latin and Greek, which up until now have been the only book cultures represented by the discipline.

The quantitative approach finds particularly fertile ground in its application to the evolution of individual book typologies, as borne witness to by the first three essays presented in the collection. ${ }^{21}$

Specifically, the first two contributions share the theme of the Bible, a favourite subject for codicological investigations on account of the central position it occupies in manuscript production in the three great civilisations of the Holy Book (Greek, Latin and Hebrew), the exceptional number of surviving examples, and the large variety of its uses, which in turn spawned a wide range of material manifestations. From a systematic survey of the structural characteristics of a corpus of giant Latin Bibles manufactured between Rome and Tuscany over the span of a

contributed to intensifying the disagreement between the 'quantitativists' (even if they are of humanist derivation) and advocates of more traditional methods.

21 See, in particular, the contributions of Frank M. Bischoff (17), Lucien Reinhout (19) and Michel Trigalet (3). Among the pioneers of a serial approach to the study of the manuscript book (albeit limited to the application of statistical analysis to the synthesis and description of the collected data), certainly worthy of mention are Albert Derolez (of whom, see, in particular, Derolez 1984) and Malachi Beit Arié (whose theoretical positions-in contraposition with those outlined out in [Ornato et al.] 1997-are summarised in Beit-Arié 2003). 
little more than a century (1), ${ }^{22}$ a picture has emerged of a production type characterised by a number of features that guarantee its recognition (e.g. size, script, decorative typology, arrangement in text blocks corresponding to an exclusive sequence of quires, and the stability of certain textual series), but at the same time one which is marked by peculiarities that make it possible to characterise individual specimens in synchrony and to identify clusters of Bibles. Additionally, the said picture makes it possible to document, materially, the transition between two distinct periods and production contexts. The first was focused in the 'UmbroRoman' area, which remained strongly attached to monastic production methods, and was driven by a specific doctrinal and political agenda, whereas the second was oriented towards an urban context and entrusted to a team of professional artisans employed by specific patrons so as to satisfy the wishes of communities of worshippers attracted by the prestige to be gained through the acquisition of a single 'codex-monument'.

The second contribution (2), ${ }^{23}$ part of a wider research project, ${ }^{24}$ rests on a corpus of more than 1,500 manuscripts (approximately 350 of which have been examined first-hand), and entails the study of pocket-sized Latin pandects, the portable one-volume Bibles intended for individual rather than institutional use that began to appear at the beginning of the $13^{\text {th }}$ century. Thousands of these were disseminated, above all in France (especially in Paris, the centre of the most advanced experimentation), and in England and Italy as well. The miniaturisation of the entire Bible called for the successful combination, in the academic setting, of specific manufacturing techniques - ranging from the production of extremely thin parchment to the assembly of rather thick quires, and a very dense mise en page - aimed at minimising a volume's size without compromising its legibility. Such techniques can undergo comparative analysis by referring to the manuscripts' places of origin (by means of serial analysis, which makes it possible to reveal important differences, small ones included), thereby providing valuable clues for establishing the attribution of specimens which lack explicit details visà-vis place of origin. This is the case with regard to quiring preferences, the presence and frequency of interruptions (i.e. caesurae) in both material and textural continuity (e.g. in the centre of the volume, between AT and NT, or preceding final paratexts), as well as graphic and perigraphic strategies employed to accommodate particularly long texts in a volume of small size.

22 Maniaci 2000a.

23 Ruzzier 2013.

24 The author's doctoral thesis (Ruzzier 2010), currently awaiting publication in the form of a monograph. 
If the Bible represents a favourite subject for quantitative research, the same approach can be applied with equal success to other types of content, such as Latin hagiographic literature (e.g. biographies, passiones, histories of relics, miracle collections) dating from Antiquity up to the end of the Middle Ages. The presentation of a project (3) 3$)^{25}$ based on a vast quantity of data ${ }^{26}$ has the virtue of clearly articulating a series of pertinent issues specifically related to the creation and systematic exploitation of a hagiographic dossier based on secondary sources, but in large part also shared with texts of different content. Such issues include the dearth of codicological and textual descriptions in the oldest catalogues (often the only ones available); uncertainties in relation to the dating and geographical pinpointing of texts and manuscripts; the challenge of deducing from descriptions the nature of manuscripts (e.g. unitary or 'complex', organised or random ensembles); the instability of texts owing to frequent revision and updating; the absence of adequate critical editions; the difficulty of assessing survival and loss rates; and the necessity to combine the evidence provided by manuscripts with that originating from other types of sources. More specific problems have to do with the delimitation and treatment of hagiographic texts often handed down within thematic collections (legendaries), but also in broader contexts (e.g. hagiographical manuscripts, Bibles, collections of an encyclopaedic nature), or in the form of abridged collections of various sizes. Notwithstanding the limitations of the sources, the statistical treatment of the available data facilitates the reconstruction of the dissemination of manuscripts recounting the life histories of individual saints, and the overall production trends of different types of hagiographical text produced between the $13^{\text {th }}$ and $15^{\text {th }}$ centuries in various areas of Europe, in relation to the changes that occurred in the general public and in the liturgy. ${ }^{27}$

A second group of essays exemplifies the potential for the application of statistical analysis to the two predominant writing supports employed in the Greek and Latin manuscript traditions: parchment and paper.

One of the contributions $(4)^{28}$ is dedicated to the characteristics of the parchment used by Byzantine artisans. The essay exploits 'peripheral' information gathered as part of wider research into the underlying principles and

25 Trigalet 2001.

26 The Legendiers database, conceived by Guy Philippart and subsequently merged with the electronic version of the Bibliotheca Hagiographica Latina manuscripta (BHLm) (http://bhlms.fltr.ucl.ac.be/; last accessed 07/09/2021).

27 Some preliminary results from the research are reported in Philippart / Trigalet 2008.

28 Maniaci 2000b. 
layout techniques of parchment codices dating from the $11^{\text {th }}$ and $12^{\text {th }}$ centuries. ${ }^{29}$ The study addresses, in particular, the relationship between support quality (assessed on the basis of the frequency and distribution of defects-viz. holes and lisières (i.e. untrimmed edges)-and the gauging of sheet thickness), and the basic data for the characterisation of a codex (i.e. data, origin, content). Close study of the strategies adopted by artisans for the handling of defects also forms part of a general assessment of writing support quality. The contribution shows how a seemingly secondary aspect of book manufacture can in fact represent a rich source of information from a statistical perspective, owing to the highly variable distribution of defects in manuscripts and the possibility of counting them, by means of a very simple procedure (i.e. the tallying up the 'number of bifolia affected by holes'). The count does not merely establish the total number of defects, but also their distribution throughout the codex, in single quires, and on the surfaces of individual pages. Aside from an obvious (and rather predictable) correlation between defects and textual typesamongst of which the Bible, across its many witnesses of different shapes and production levels, appears always to have been made using the best available material-the data analysis reveals a general tendency towards a reduction in the quality of the parchment used during the transition between the two centuries in question, as part of a global decline in book production quality, of which it constitutes (along with a tendency for an increase in page filling) a clear indication. An examination of defects also makes it possible to, as it were, step into the artisan's workshop, and draws attention to the effort he made to minimise hindrances to the reader (by discarding, whenever possible, parchment marred by holes within the writing area), and to safeguard the book's aesthetic qualities by 'hiding' bifolia disfigured by the presence of holes and lisières in the middle of quires and towards the end of a codex. Generally speaking, the analysis shows how, already at the moment when the artisan selected his material, he oriented his choices in relation to the content and the overall quality of the volume to be made, at the same time as adopting in a fully conscious way a series of measures aimed at minimising the functional and aesthetic impact of the defects. $^{30}$

29 Maniaci 2002a.

30 For an example of the sheer quantity of information on artisanal practices that can be gleaned from the statistical 'exploitation' of a seemingly minor detail, such as parchment thickness, see Bianchi et al. 1993. 
Medieval paper produced in Italy is the subject of two contributions by Ezio Ornato, one of the founders of quantitative codicology. ${ }^{31}$ In contrast to parchment, paper-a handcrafted product that could be made to meet any specifications required by the scribes and printers-is a material that has a lot more to 'say', since sheets bear in their weft and warp a quantity and variety of information particularly suitable for systematic study and a sophisticated historical reading, facilitated by the intersection between archaeological data and the information that can be gleaned from written sources. Among the characteristics of Western paper originating from Italy, which from the end of the Middle Ages onwards was distributed widely throughout Europe, the watermark stands out because of the close attention it has received, chiefly thanks to the power of suggestion exerted by the motifs employed and the potential they hold for the dating of written documents. In contrast to traditional dating procedures, which are susceptible to inaccuracies and uncertainties and are dependent upon other criteria related to palaeographical and philological expertise, the application of statistical analysis makes it possible to obtain more accurate and reliable results, as demonstrated by an experiment carried out on a sample consisting of more than 60 'letter P' watermarks drawn from a database of motifs identified in incunabula originating from the Low Countries (5). ${ }^{32}$ The method calls for the definition, based on a set of specifically defined measurements, of a 'dissimilarity index' for each of the dated watermarks within the corpus in comparison to all the others (calculated on the basis of a predefined number of 'nodal points'), and the coupling of a 'chronological gap' to each comparison. Such a procedure enables one to construct a grid within which it is possible to insert the undated watermarks (with a level of accuracy and reliability that can be measured through empirical tests, depending on the size and relevance of the comparison sample, as well as on the number of watermarks surveyed for a given motif). Also in this instance, the efficacy of the method is linked to the capacity of the scholar to recognise and to control the factors that can compromise reliability (such as the quality of the image, measurement errors, the choice of relevant points, and the use of other similarity criteria-e.g. the distance between the chain lines / laid lines-and the statistical validation of results).

The potential of the quantitative study of watermarks extends far beyond the 'auxiliary' function offered by dating procedures, as the second of the two

31 Standing out amongst the plentiful contributions dedicated to the topic is Ornato et al. 2001.

32 Ornato 2004. 
essays of a methodological nature focused on paper shows (6). ${ }^{33}$ Born of the need to endow paper produced in the various paper mills with a specific 'maker's mark', the custom of distinguishing between sheets by means of a wide variety of motifs, grouped into types exhibiting obvious morphological differences, became enhanced over time with a multiplicity of features of a qualitative nature aimed at specifying a sheet's dimensions, its level of whiteness, and other characteristics of a manufactured material used for an increasingly wide range of applications, especially at a point in time when the artisanal context of manuscript production ran parallel to, and was progressively replaced by, the new system for printed book manufacture. If it seems reasonable to suppose that the paper stocks that the copyists had access to were not only quantitatively smaller, but also typologically more uniform than those purchased by printers through middlemen who obtained their supplies from a number of different paper mills, the comparison of two series of incunabula belonging to two different editions printed in Venice highlights the complexity of the notion of 'stock heterogeneity', and reveals how the mixture of motifs and paper types served to assist wholesalers in regulating both the gradation of paper hues and the homogeneity of the consignments of paper sold to the printers, depending on the quality of the edition to be manufactured (i.e. the needs and financial resources of potential buyers). Not by chance, the stocks of paper used in the most popular editions show a higher degree of heterogeneity, but it is also the case that the same watermark motif can correspond to different degrees of whiteness and hence to different quality grades, even within one and the same print run. The ability of the scholar to formulate new questions and to apply them to sufficiently populated corpora of watermarks makes it possible to shed light on an aspect of the organisation of the printer's work which otherwise could not be reconstructed. When addressed in this way, the systematic study of watermarks proves itself to be rich in further potential-potential which is still far from being fully investigated.

The quantitative approach proves itself to be particularly well suited to the study of book manufacturing techniques, given the conservative nature of artisanal practices, the slowness with which innovations emerged and developed, and the necessity to work on large corpora so as to be able to follow, diachronically, evolutionary trends and to account for individual synchronic variations in relation to internal and external factors to the world of books. Unfortunately, the codicological information offered by the available descriptions is generally rather thin on the ground, lacking in detail and presented in different ways from

33 Ornato 2014. 
one catalogue to another (when not within one and the same catalogue), and therefore renders very difficult the planning and realisation of specific research projects, even when based on parameters which are intrinsically easy to count and measure.

An exemplary case is found in the study of the evolution in the 'thickness' of quires (i.e. the number of bifolia) in Europe from the middle of the $12^{\text {th }}$ century up until the end of the Middle Ages, when a centuries-long domination of the quaternion comes to an end in the manufacture of the Latin codex (7). ${ }^{34}$ The investigation is based on a representative corpus drawn from catalogues of different ages, quality and structure. Its set-up represented a serious challenge, not so much as regards the detection of the most widespread form of quiring, mainly provided for by the descriptive protocols, but above all on account of the erratic mention of and inconsistent way in which other variables considered relevant for the evaluation of the phenomenon are recorded (e.g. the sheet folding format, the ruling technique, or the presence of quire signatures or catchwords). In spite of the severe constraints imposed by the nature of the sources, quantitative analysis makes it possible to better define the various stages in the transition from the widespread use of the quaternion to a significantly greater variety of quire typologies, at rates and preferences that differ in the various areas of Europe: the early acceptance and establishment of the senion in the English context (starting in the first half of the $13^{\text {th }}$ century) is followed by its later adoption in France (with the return of the quaternion, in both contexts, in the middle of the $14^{\text {th }}$ century), whilst in Italy, from the $15^{\text {th }}$ century onwards, the use of the quinion clearly prevails. The analysis of the relationship between quiring and content shows how innovations matured in the university context and tended to spread in the production of paper volumes, probably on account of the perception that the new support was not very robust. In this case just as in other cases, a shared reflection on the current cataloguing rules and codifying criteria and a standardisation of the data could facilitate, or indeed make it entirely possible to conduct research that is currently impeded by the absence or paucity of available information.

A study devoted to quire making methods in parchment codices (8) 35 offers just one example of the results that can be obtained solely through the systematic collection of seemingly 'silent' data and their statistical processing. Whilst in paper the weaving together of chain lines and laid lines and the position of the watermark normally make it possible to determine the folding format, in the

34 Busonero 1999.

35 Maniaci 1999a. 
case of parchment the clues that allow us to reconstruct the relationship between the bifolium and the original animal skin are far less conspicuous and are not always visible on the material's surface. The clues to look for are the dorsal axis, the lisières, the marks left by holes, the streaks that sometimes straddle multiple surfaces, and above all the areas around the axillae, which are thinner and more porous than elsewhere on the skin. Indeed, it was the systematic surveying of the last mentioned-the axillae-in a sample of Greek codices that enabled to challenge, on an objective basis, Gilissen's rather shaky 'deterministic' hypothesis on the creation of bifolia by means of one or more successive folds of parchment sheets (i.e. folio, quarto, octavo), thereby revealing the possibility of an asymmetric division (i.e. sexto) which makes it possible to obtain from a single skin three bifolia instead of two, in such a way so as to maximise the simultaneous use of skins of different sizes. This hypothesis is supported by the distribution trend of the axillae, which do not consistently appear in the same position within one and the same volume (as Gilissen's reconstruction implies), and by the relative frequency of their attested locations. Quantitative verification, albeit confined to a limited sample, allows us to place parchment manufacture in a context where the available skins-obtained from animals that were first and foremost raised for other purposes-were not all of uniform size, and the craftsmen were not overly concerned about saving time or limiting the steps necessary to make quires; rather, they were more interested in optimising their use of the material available to them.

A seemingly causal and 'silent' element such as the number of horizontal lines ruled within the writing area (or rather the frequency of even and uneven multiples of $n$ lines) can also serve as the subject of sophisticated statistical analysis, with the aim of uncovering information concealed behind a distribution pattern that clearly differs with the frequency predicted by the laws of probability $(9)^{36}$ - on condition, again, that the information drawn from the catalogues be in a form which is eminently suitable for processing. Once again, the explanation for an unexpected phenomenon lies in a careful examination of a pre-existing corpus of volumes in which a number of parameters have already been revealed (to fulfil various other objectives), whose relationship with the writing lines trend can prove interesting to analyse. Such parameters include the ruling type and technique (especially the presence, in certain places, of 'overrun' lines, extending beyond the normal writing lines); the position of the writing either above or below the top line; and the height of the writing area (which in larger codices probably afforded the artisan a greater degree of flexi-

36 Muzerelle 2012. 
bility in the distribution of the writing lines). Indeed, the trend observed in the figures reveals some clear correlations which, broadly speaking, are easy to explain. Conspicuous amongst these is a significant concentration of types without 'overrun' lines in codices ruled in ink, among which predominate layouts with an even number of writing lines. One can infer, indirectly, the widespread use of a 'rake', that is to say a comb-like tool, endowed with an even or uneven number of teeth, which when used successively in a sequence produces a rate of $75 \%$ for rulings with an even number of lines and a rate of $25 \%$ for rulings with an uneven number of lines. The analysis reveals some further significant correlations, such as the relationship between the positioning of writing either above or below the top line and the technique used for drawing lines, for which, however, it is less easy to provide a plausible explanation.

The manufacturing theme also encompasses the study of the 'complex' ('modular' or 'open') nature of the book in the form of a codex, where structuring into quires made it possible (and easy) to modify content by adding or removing material, or through its alternative arrangement. Given the difficulty of carrying out direct examinations and in-depth investigations of samples of a statistically significant size, if we wish to make a preliminary assessment of the various manifestations of complexity in the codex and to devise a nomenclature for its description, it is necessary to utilise the available-although unsatisfactory-information that can be gleaned from catalogues. A contribution that focuses on the Byzantine manuscript $(10)^{37}$ provides a broad view of the textual typologies on the basis of which such volumes can be lumped together (albeit limited to materially unitary volumes). In particular, the relationships between the size, thickness of the book, number, length and position of texts, textual typology and degree of thematic consistency, and the exploitation of the page are observed. Also drawn attention to are factors which, depending on the various eras, influenced the unification of content, a phenomenon that shows obvious growth in the closing centuries of the Middle Byzantine period. Far from being a chance phenomenon, the simultaneous presence of multiple texts within one and same codex seems to be determined by material concerns, and is governed by the essential antinomy between the length of texts (expressed as the number of leaves) and the aesthetic and functional requisites that the book in the form of a codex cannot disregard.

If the topic of the complexity of the codex, which centres on the analysis of the interrelationship between the book's materiality and its content, has been afforded ample space in the codicological literature in recent years, the contri-

37 Maniaci 2004. 
bution on the 'third dimension of the book' (11) ${ }^{38}$ addresses it from a hitherto unexplored perspective, namely the thickness of the book block, corresponding to the height of the 'box' that contains the text (i.e. the stack of quires). In contrast to the other two dimensions-the height and width of the page-thickness is never mentioned in catalogues (it is not by chance that a specific and unambiguous term to describe the same is lacking). An indirect estimate of it, even if approximate, is however provided by the block's number of leaves or bulk. By scrutinising a composite sample derived from a perusal of a large number of catalogues of Latin codices (already assembled to carry out previous research), the authors of the essay draw on elements useful for pondering the dialectical relationship between the codex's volumetric value and its capacity, which is to say the amount of text it can accommodate, understood as the number and length of the texts it contains. If the bulk of the Latin codex tends to increase over time in relation to changes in intellectual requirements and manufacturing contexts which occurred during the $12^{\text {th }}$ century with the shift from monastic to urban production, the evolution tends to take place in line with an aesthetic link that ties the number of leaves (i.e. the bulk of the book block) to the other two dimensions of the page. On average, large codices contain a greater number of leaves in comparison to smaller ones, and the exceptions (which present in the form of very 'chunky', small codices) can be accounted for, in the Late Middle Ages, by the necessity to pack a large amount of text into 'containers' of a readily manageable or pocketable size, with attention paid to the number of leaves, as well as to the exploitation of the page. The constraints in relation to the capacity of the codex are also reflected in the rate of multi-textuality that resulted from the merging of slim texts; such texts predominated throughout the Middle Ages and could not be circulated as single volumes. In addition, slim texts were for the most part grouped together around a 'flagship' text, usually placed at the beginning of a volume. This, and other findings presented in the article, demonstrate an interest in an area of study that remains little explored, but one which certainly holds potential for further development.

The immediate availability of readily measurable parameters, together with the intrinsic richness of the subject matter and the challenge presented by the scarcity of written sources, explains the huge success of the layout (or mise en page) among the fields of interest addressed by statistical codicology.

Dedicated to the vanishingly small number of ancient layout 'recipes' that survive today is an analysis (12) ${ }^{39}$ that highlights operating mechanisms and

38 Muzerelle / Ornato 2004.

39 Maniaci 2015, which builds on and delves further into Maniaci 1995. 
compares their characteristics, thereby uncovering the existence of some important constants (in relation to the distribution of written and unwritten spaces or the relationships between margins), as well as some equally significant differences between the rules attributable to different historical periods and book cultures. On the methodological plane, the difficulty of interpreting the small number of surviving texts-not infrequently rather obscure and omissive onesand above all of recognising the application of the directions they prescribe in individual codices or in specific groups of manuscripts, emerges. The work that has to be done in order to understand the canons applied by medieval artisans certainly entails a dimensional analysis of layouts borne tangible witness to in ancient manuscripts. Such an analysis poses complex-and as yet unresolvedproblems vis-à-vis the appraisal of margins of error caused by an accumulation of craftsmen's inaccuracies, imprecise measuring instruments, deformations induced (in parchment manuscripts) by the passage of time, and dimensional changes caused by trimming. ${ }^{40}$

The limitations mentioned above do not preclude the possibility of following diachronically, at a macroscopic level, the 'graphical presentation' of manuscripts (starting from the earliest parchment books in the form of a codex, all the way up to the end of the $12^{\text {th }}$ century), and comparing, era-by-era, the working methods established in the Greek East and the Latin West (13)..$^{41}$ Once again, it is

40 The interpretation of the most recent of the surviving sources-that of the $16^{\text {th }}$-century mathematician Sigismondo Fanti-has been challenged by Agati / Gavrila 2015, who more generally have criticised the presuppositions upon which the method I used for the analysis of the recipes was based. The expository tone and style of the article-which presents observations of a prosopographical-codicological nature (weighed down by lengthy scholarly digression) alongside abstract mathematical considerations, bearing no relation to the subject in question-have up until now led me to rely on the reader's capacity to independently appraise the quality and validity of the arguments formulated by the two authors. Regarding the reconstruction, here I shall confine myself to remarking that their reading (a) stretches the meaning of the stipulations set down in Fanti's text (in which the phrase 'it should be as much white as black' must unquestionably be understood to refer to a two-column volume and interpreted in linear rather than superficial terms-the comparison between surfaces not by chance being absent from all the recipes); and (b) violates a number of the most consistent features of the mise en page in Greek and Latin codices (verified across several thousand manuscripts), assuming a writing area of more ample proportion than that of the book, a page filling rate of more than $54 \%$, and a relationship between the lower and external margins equal to $1: 2$, which is not seen in the Late Middle Ages. Above all, the purely theoretical reconstruction advanced by the two authors is not supported by any experimental verification apart from an essentially insignificant reference to the measuring of the writing area in five (!) printed specimens of Fanti's treatise (p. 135).

41 Maniaci 2012. 
the availability of corpora, no matter how disparate, already assembled for previous research projects, in association with the systematic perusal of invaluable collections such as Elias Avery Lowe's Codices Latini Antiquiores, which makes it possible to create a database of sufficient magnitude so as to be broken down into sub-groups of a significant size, formed through the intersection of variables considered to be potentially meaningful. By means of a comparative analysis of the basic characteristics of the mise en page-i.e. size, ruling, delineation and utilisation of the spaces-some shared trends emerge in the evolution of the codex's form, in addition to some significant structural differences. In relation to the page's appearance and the techniques used in laying out its content, one observes (in particular) a tendency for the Greek artisan to remain faithful to the practices developed in Late Antiquity, in contrast to the greater dynamism seen in the Latin context from the beginning of the Middle Ages. If the reference sample does not enable one to venture beyond the identification of a few general trends, the results obtained should be further examined in relation to specific contexts, and research should be extended to the centuries of the Late Middle Ages and to other book traditions, based on specific perusals.

A contribution that focuses on a particular type of content and an especially complex form of layout is based on an analysis of 41 manuscripts and 163 annotated incunabula of the Codex Justinianeus, in which the main text is accompanied by a large amount of commentary (14). ${ }^{42}$ When designing and realising the layout of an annotated book (on any subject), the artisan had to manage, simultaneously, two streams of text; in other words, he had to tackle the dual problem of synchronising them (i.e. keeping the gloss as close as possible to the corresponding passage), whilst at the same time accentuating the link, thereby easing the toing and froing of the reader's eye from one text to the other. ${ }^{43}$ These problems present themselves afresh, albeit in very different technical circumstances, in the realm of printing, thus giving rise to alternative solutions in the two distinct manufacturing contexts. The example of the juridical book, and in particular the volumes containing the Codex, in which a relatively standardised commentary is arranged as a sort of 'frame' around the work to which it refers (in accordance with a highly codified layout), facilitates the characterisation and comparison of solutions devised in the different contexts in which manuscripts and incunabula were produced, whose apparent visual similarity in fact conceals significant differences, owing to the peculiarities of the respective

42 Devoti 1999.

43 For a theoretical discussion of the analytical parameters applicable to the pages of glossed codices, see Maniaci 2002b. 
manufacturing techniques. In the case of the manuscript, synchronisation between the text and the gloss is achieved page after page; the central area, reserved for the main text, is kept stable, whilst the surrounding and marginal glosses are added in a more flexible way. Conversely, in the printed book, whose manufacturing technique called for a preliminary distribution of the text throughout the entire volume, the marginal area remain fixed, while the internal area-particularly the columns of script-varies, in order to withstand the burden, as it were, of the adjustments necessary for the synchronisation of the text and gloss.

The proposed analysis model for juridical codices-based on the subdivision of the page into sectors and on the measurement of the respective surfaces-lends itself to being extended, when suitably modified, to other types of glossed codex. An example of the method's extended application can be found in the investigation of a small group of manuscripts of Homer's Iliad which present-as is normal in the Middle Byzantine period-the commentary arranged as a 'frame' around the central text, and in particular along its three 'free' sides (15). ${ }^{44}$ This layout technique calls for a patient and laborious measuring and counting process aimed at establishing the length of the individual scholia, their position on the page, the distance from the annotated passage, the presence and frequency of abbreviations, the density of the commentary in relation to the main text, the alternation between glosses of different lengths, and so forth. The application of a highly detailed analysis protocol to an individual book, endowed with particularly heavy annotation, makes it possible to identify the ways in which the scribe tackled the problem of synchronising the two bodies of text and then making the necessary adjustments between individual glosses and the corresponding passages of text through the use of various linkage mechanisms, such as symbols, numbers, or lemmata that reiterate the opening words of the glossed text. If the comparative examination of 'twin' manuscripts, carried out during a previous study, ${ }^{45}$ facilitates an assessment of the skill of the respective scribes, the comparison of two later codices, of smaller size, brings to light the problems raised by the reduction in the area of the available surfaces and the various solutions adopted by the copyists in order to address them, whether through a more intensive exploitation of the available space, or by drastically cutting back on the amount of commentary (unless part of the omitted annotation is recovered later on, with an inevitable alteration of the original sequence).

44 Maniaci 2006a.

45 Maniaci 2006b. 
Irrespective of its content and the complexity of its spatial arrangement, the construction of a page tends primarily to favour the legibility of the text-a rather complex notion, but one which can nonetheless be broken down into quantifiable and measurable elements. ${ }^{46}$ Among these we can include the division or 'splitting' of words at the end of lines. This is a widespread phenomenon, and an only seemingly negligible one: indeed, the division of words constitutes an obstacle to an uninterrupted reading flow, and therefore constrains the copyist to adopt strategies aimed at minimising the necessity to start new lines or to signal their presence to the reader. The study of the frequency of split words, whose distracting influence on the reader varies depending on their position on the page and in relation to the quire, necessitates the development of a model that makes it possible to compare the actual frequency with that predicted by a probability calculation. When applied to a corpus of Byzantine manuscripts (16),,$^{47}$ the comparison confirms, overall, an awareness of the phenomenon on the part of the Greek scribes and makes it possible to observe how they approached it, depending on the interaction-not always easily interpretable-between other characteristics of the codex (e.g. the number of characters per line, the arrangement of the text, the writing's features, the frequency of abbreviations, content, and the degree of the layout's development), thereby enabling us to recognise in the more learned and well-informed readers (i.e. those who read secular codices and heavily annotated ones) keener attention paid to limiting word division. Clear confirmation of the 'non-neutrality' of the phenomenon also emerges from the study of word splits, which prove to be distinctly less frequent in relation to the final line of the writing area, and above all are avoided between the recto and verso of a page (where the visual unity of the word faltered), but also with the transition from one quire to the next, which was clearly perceived as a sort of boundary.

The last section of the collection gathers together a small selection of works that pivot on the figure of the scribe, observed as a distinct individual in the act of writing, or as a member of a group working within specific contexts.

The contribution dedicated to a precious Latin Gospel Book produced by the Benedictine monk Herimann at Helmarshausen Abbey in the second half of the $12^{\text {th }}$ century $(17)^{48}$ sheds light-by means of an innovative application of the statistical analysis of time series to micro-variations observed in the graphic trail-on the ways in which an individual scribe was able to control the spaces between letters in a conscious effort to vary the density of his script in relation to the tran-

46 For a theoretical framework on the issue of legibility, see Bergeron / Ornato 1990.

47 Maniaci 1997.

48 Bischoff 1996. 
scription needs. In addition to shedding light on the strategies adopted by Herimann for the optimal management of the link between content and the page, by taking into account the internal divisions within the evangelical text and the ornamental elements, the analysis of cyclical fluctuations reveals voluntary and involuntary phenomena that elude a simple visual inspection-for example, the systematic compression of the script in the opening lines of each page and the first part of a quire (an expedient that afforded Herimann a degree of flexibility when it came to respecting his own text distribution plan), or alternatively, more spaced out lettering on the flesh side than on the hair side, which was probably more resistant to the smooth passage of the writing instrument.

Analysis of the factors that influence the writing rhythm represents a fascinating area of study, and one which could take advantage of emerging technologies in digital palaeography in order to automate and examine more closely the data to be processed.

In the successive contribution (18), ${ }^{49}$ we shift from observing the behaviour of an individual scribe to an analysis of the dynamics underlying the copyist's gesture. The theme is addressed through a re-examination of the somewhat controversial notion of the 'modular ratio', that is to say the relationship between the width and height of the nuclei of letters, identified by Léon Gilissen as the distinguishing feature among the hands of a group of copyists executing one and the same type of script. Picking up afresh on the main argument in Ezio Ornato's criticism of Gilissen's approach, ${ }^{50}$ Denis Muzerelle delves into the reasons why the modular ratio cannot be considered a constant characteristic of individual scribes; in fact, it depends on the size of the writing, in the sense that the proportion of characters is consistently wider in scripts of smaller module size. The phenomenon, which is of a geometric nature, can be attributed to the interaction between the nib of the pen, which in small writing cannot be reduced proportionally to the size of the nuclei, and the angle of the cut edge of the pen's nib in relation to the sheet, depending on the way in which the pen was held by the copyist. If, then, the analysis of the modular ratio proves to be of little importance on the palaeographical plane, the study of the correlation between the modular ratio and the page's characteristics, verified in a sample of the output of some Late Medieval scribes working for Malatesta Novello, lord of Cesena, demonstrates how the most prolific copyist of the local scriptorium, Jean d'Épinal, spontaneously adapted the proportions of his less formalised writing to the layout of the text, tending to

49 Muzerelle 1999.

50 See above, note 8 . 
'compress' it in two column manuscripts, and contrarily to stretch it out in full page layouts, in the presence of a broader space over which his pen could run.

The next essay in the collection is dedicated to subscription formulae-, in other words, colophons added by scribes at the end of their transcriptions. Colophons are documents that contain a wealth of information on the circumstances, key actors and methods employed in the production of manuscript books. Colophons can vary in their structure and content. They are chiefly used as sources of single items of information, and are only seldom the subject of serial analyses, such as the one conducted by Lucien Reynhout, subsequently presented in a volume dedicated to the presence of (and changes undergone by) around thirty formulae identified in works dating from Late Antiquity up until the age of $\mathrm{Hu}$ manism, ${ }^{51}$ whose methodological premises are illustrated in the contribution reproduced here (19). ${ }^{52}$ The author underscores the necessity to work on a representative population, identifying within the attested formulae typological groups based on potentially significant variables; he then goes on to interpret the results based on historical-cultural factors and the endogenous mechanisms underlying the first appearance and evolution of the formulae. As well as the analysis of the formulae, the study of colophons offers the quantitative codicologist an almost virgin field of application vis-à-vis the analysis of their content and structure, the transformations they underwent over time, the relationship between the information they provide and the content (or other aspects) of the codex, and graphical and codicological presentation criteria. The adoption of a comparative approach, aimed at revealing similarities and differences, and loans from one book tradition to another, appears to be of particular interest.

Amongst the information offered by colophons, albeit to a lesser extent in comparison to dating, we find the geographical pinpointing of manuscripts' origins, data whose systematic exploitation can be useful when reflecting on the notion of a scriptorium, which constitutes, in the Latin production context, and particularly up until the end of the $13^{\text {th }}$ century, an inescapable point of reference, albeit one whose profile remains somewhat vague (20). ${ }^{53}$ The large quantity of data extracted from the French catalogues of dated manuscripts (CMD), combined with information drawn from the corpus of French cartularies, enabled the essay's author to re-evaluate, on a firmer footing, despite being affected by inevitable distortions, the geographical distribution of surviving codices: Northern France stands out for its density of copying centres, in contrast to the country's south-

51 Reynhout 2006.

52 Reynhout 2001.

53 Muzerelle 2015. 
central regions, which were less favourable-for geographical, historical-religious and economic reasons-to the establishment of monasteries. Alongside geographical mapping-which paints a highly complex picture of the notion of a scriptorium-a close perusal of the $C M D$ series provides the raw material that makes it possible to conduct a comparative analysis of monastic and episcopal production centres, and deepens, within a 'palaeographic landscape' which has been substantially redefined in comparison to previous research, our knowledge of individual entities made distinct by an important legacy of geographically pinpointed codices.

The broad selection of essays assembled in the present volume offers a rich panorama-albeit an inevitably incomplete one-of specific contexts and themes for which statistical analysis has proved to be a particularly worthwhile and productive approach. Indeed, it is perhaps the only one capable of revealing phenomena which would otherwise elude approaches based on the analysis of individual cases and scenarios, with the aim of characterising trends and investigating underlying motivations.

As well as testifying to the wide range of elements and aspects of the history of the manuscript book that can be tackled through quantitative analysis, the essays presented here in translation are intended to contribute to the exemplification of a methodology which, despite being unitary in its fundamental principles, defines and adapts, time after time, strategies and investigation tools in accordance with specific themes and objectives, on the grounds that

[...] every research project comes with its own set of characteristics; therefore each project calls for specific observation protocols, the formulation of ad hoc investigation and validation procedures, and hence the creation of specific tools, which sometimes even have to be invented from scratch. ${ }^{54}$

If it is up to individual scholars to pose any relevant questions, to select the necessary materials to address them, and to identify the most suitable approaches to

54 '[...] chaque recherche possède ses propres caractéristiques; elle requiert donc l'élaboration de protocoles d'observation particuliers, la construction de procédures ad hoc d'enquête et de validation, ainsi que la constitution d'outils spécifiques qu'il faut chaque fois littéralement inventer' (Ornato 2013, 203). 
deliver scientifically based answers, ${ }^{55}$ the indispensable prerequisite lies in a mastery of methods, and hence in the possession of a basic knowledge of the techniques and associated tools that are part and parcel of statistical analysis, but which unfortunately are almost entirely absent from humanities study programmes, and in particular in the training of book historians. ${ }^{56}$

All the contributions included in this collection are focused on the book in the form of a (mostly manuscript) codex, whether it be of the Greek or Latin tradition. One of the most important challenges to meet in the future with respect to the quantitative approach will consist in conducting experiments to determine the potential for its application to other book traditions, and above all to manuscripts of different book forms, so as to verify whether, to what extent, and in what way the positive results obtained in the sphere of Greek and Latin codicology might be extended to writing supports other than parchment and paper, that is to say, books in scroll form, books written on palm leaf or other materials, books in concertina or fan form, and so on; in other words, extended to cultural contexts very different from those of the medieval West and Byzantium. Only the development of research of a systematic kind, based on the gathering of samples of sufficient size and composition, and on the use of adequately detailed surveying protocols, will make it possible to demonstrate, in a broader perspective, the fecundity of a 'universal grammar of the codex' and its potential for application to other manuscript forms. ${ }^{57}$ As the theme of 'open data' becomes ever more present and central in scientific debate, the need also arises to encourage a willingness to make available all the data generated by various research projects within the

55 Not because they are vitiated by an a priori assumption of objectivity, but rather because they are verified using tools appropriate to the discipline, within the margins of error considered acceptable by the researcher.

56 An interesting experiment is the Le livre médiéval au regard des méthodes quantitatives summer school, which has been organised on an annual basis in Paris since 2016, and is the fruit of a collaboration between the Laboratoire de Médiévistique Occidentale in Paris, the Institut de recherche et d'histoire des textes, and other scientific institutions. The school provides, for graduate and post-graduate students, a general introduction to the concepts, tools and operating procedures relevant to quantitative codicology. Similar advocacy for the necessity of training, with specific reference to digital palaeography, can be found in Stokes 2010.

57 Similar questions are posed, in reference to digital methods, by Stokes 2015, 2: 'Can there be a universal model for the representation of books and handwriting? For handwriting and print? For decoration? Are modern and medieval books as different as scholarly practice seems to suggest, or can the same methods be applied to both? Can paleographers learn from typographers, and vice versa? Or is even asking these questions part of a vain "quest for universalism" [...]'. See also Krause / Hegel 2018, 350-352. 
book historians' community-a development which would necessitate a shared reflection on surveying formats and methods..$^{58}$

I owe a debt of gratitude to Michael Friedrich-the tireless and visionary driving force behind an ambitious programme of comparative research on the writing cultures of Europe, Africa and Asia ${ }^{59}$-for the stimulus he has provided in encouraging me to assemble this collection, not to mention the support he has given me throughout its realisation. I am also grateful to Cosima Schwarke for the acuity, painstaking care and readiness with which she has taken on the monumental task of editing the volume. This project benefited considerably from Mark Livesey's commitment to the translation process, not least his willingness to tackle some linguistic conundrums posed by the rendering of technical terms into a key language for scientific communication, but one which up until now has curiously lacked a standardised vocabulary; ${ }^{60}$ last but not list, I wish to thank Edmondo Colella, long-time collaborator and friend, for the care and elegance put into the realization of the numerous tables and graphs.

As this book was going to press, Denis Muzerelle sadly passed away on April 14, 2021, leaving us deprived of his vast knowledge, brilliant intellect and warm humanity. He was not only an outstanding expert and a sophisticated connoisseur of manuscripts, statistics and numerous other things, but also a dear friend to me and to many of the authors who have contributed to this volume, which is wholeheartedly dedicated to him.

58 See, in relation to this matter, Ornato 2010b, 100-113, in particular 111-113.

59 As the founder and director of the 'Centre for the Study of Manuscript Cultures' at the University of Hamburg, and the spokesperson of DFG Forschergruppe 963 'Manuscript Cultures in Asia and Africa', 2008-2011, the Sonderforschungsbereich 950 'Manuscript Cultures in Asia, Africa and Europe', 2011-2020 (the deputy spokesperson in both cases being Jörg B. Quenzer), and the 'Understanding Written Artefacts' Cluster of Excellence (the co-spokespersons being Alessandro Bausi and Kaja Harter-Uibopuu).

60 Concerning the problems posed by the translation of codicological terminology into the principal languages of scientific communication, see Maniaci 2012-2013 (with previous bibliography) and Jakobi-Mirwald 2009. 


\section{References}

Agati, Maria Luisa / Gavrila, Caius (2015), 'A proposito di un articolo recente: i precetti di mise en page di Sigismondo Fanti', in: Scriptorium, 69: 114-144.

Agati, Maria Luisa (2017), The Manuscript Book. A Compendium of Codicology, Roma: L'Erma di Bretschneider (Studia archaeologica, 214).

Albiero, Laura (2013), 'Les livres liturgiques à l'épreuve de la presse. Le cas du bréviaire de Beauvais', in Gazette du livre médiéval, 60: 28-53.

Bausi, Alessandro et al. (2015), Comparative Oriental Manuscript Studies. An Introduction, Hamburg: Tredition.

Beit-Arié, Malachi (1993), 'Why Comparative Codicology?’, in Gazette du livre médiéval, 23: 1-5.

Beit-Arié, Malachi (2003), Unveiled Faces of Medieval Hebrew Books. The Evolution of Manuscript Production - Progression or Regression?, Turnhout: Brepols.

Bergeron, Réjean / Ornato, Ezio (1990), 'La lisibilité dans les manuscrits et les imprimés de la fin du Moyen Âge. Preliminaires d'une recherche', in Scrittura e civiltà, 14: 151-198.

Bianchi, Francesco et al. (1993a), 'La structure matérielle du codex dans les principales aires culturelles de l'Italie du XI ${ }^{\mathrm{e}}$ siècle', in Maniaci, Marilena / Munafò, Paola F. (eds), Ancient and Medieval Book Materials and Techniques (Erice, 18-25 September 1992), I-II, Città del Vaticano: Biblioteca Apostolica Vaticana (Studi e Testi 357-358), II, 363-456.

Bianchi, Francesco et al. (1993b), 'Facteurs de variation de l'épaisseur du parchemin italien du VIII' au XVe siècle', in Maniaci, Marilena / Munafò, Paola F. (eds), Ancient and Medieval Book Materials and Techniques (Erice, 18-25 September 1992), I-II, Città del Vaticano: Biblioteca Apostolica Vaticana (Studi e Testi 357-358), I, 95-184 (repr. in [Ornato, Ezio et al.] [1997], La face cachée du livre médiéval. L'histoire du livre vue par Ezio Ornato, ses amis et ses collègues. Avec une préface d'Armando Petrucci, Roma: Viella [I libri di Viella, 10], 275-345).

*Bischoff, Frank M. (1996), 'Le rythme du scribe. Analyse sérielle de la densité d'écriture dans les évangiles d'Henri le Lion', in Histoire et mesure, 11, 1-2: 53-91.

Bozzolo, Carla et al. (1989), 'Une machine au fonctionnement complexe: le livre medieval', in Bady, Paul / Laufer, Roger (eds), Le texte et son inscription. Actes du colloque organisé par le Centre d'études de l'écriture de l'Université de Paris VII et le Groupe Paragraphe de l'Université de Paris VIII, Paris: CNRS, 69-78 (repr. in [Ornato, Ezio et al.] [1997], La face cachée du livre médiéval. L'histoire du livre vue par Ezio Ornato, ses amis et ses collègues. Avec une préface d'Armando Petrucci, Roma: Viella [I libri di Viella, 10], 87-95).

Bozzolo, Carla / Ornato, Ezio (1980), Pour une histoire du livre manuscrit au Moyen Âge. Trois essais de codicologie quantitative, Paris: CNRS: (Publications de l'équipe de recherche sur l'humanisme français des XIV et $\mathrm{XV}^{\mathrm{e}}$ siècles. Textes et études, 2).

*Busonero, Paola (1999), 'La fascicolazione del manoscritto nel basso medioevo', in Busonero, Paola / Casagrande Mazzoli, Maria Antonietta / Devoti, Luciana / Ornato, Ezio, La fabbrica del codice. Materiali per la storia del libro nel tardo medioevo, Roma: Viella (I libri di Viella, 14), 31-139.

Busch, Hannah / Chandna, Swati (2017), 'eCodicology: The Computer and the Mediaeval Library', in Busch, Hannah et al. (eds), Kodikologie und Paläographie im digitalen Zeitalter 4 / Codicology and Palaeography in the Digital Age 4, Norderstedt: BoD, 3-23.

Coq, Dominique / Ornato, Ezio (1987), 'Les séquences de composition du texte dans la typographie du XV e siècle: une méthode quantitative d'identification', in Histoire et mesure, 2: 87-136.

Coq, Dominique / Ornato, Ezio (1988), 'La production et le marché des incunables. Le cas des livres juridiques', in Aquilon, Pierre / Martin, Henri-Jean (eds), Le livre dans L'Europe de la Renais- 
sance. Actes du colloque international d'études humanistes (Tours 1988), Paris: Promodis, 1988, 305-322 (repr. in [Ornato, Ezio et al.] [1997], La face cachée du livre médiéval. L'histoire du livre vue par Ezio Ornato, ses amis et ses collègues. Avec une préface d'Armando Petrucci, Roma: Viella [l libri di Viella, 10], 227-243).

Derolez, Albert (1984), Codicologie des manuscrits en écriture humanistique sur parchemin, I. Texte, II. Catalogue, Turnhout: Brepols (Bibliologia, 5-6).

D’Ottone, Arianna (2006), I manoscritti arabi dello Yemen: una ricerca codicologica, Roma: La Sapienza Orientale - Ricerche.

*Devoti, Luciana (1999), 'Un rompicapo medievale. L'architettura della pagina nei manoscritti e negli incunaboli del Codex di Giustiniano', in Busonero, Paola / Casagrande Mazzoli, Maria Antonietta / Devoti, Luciana / Ornato, Ezio, La fabbrica del codice. Materiali per la storia del libro nel tardo medioevo, Roma: Viella (I libri di Viella, 14), 143-206.

Gilissen, Léon (1973), L'expertise des écritures médiévales. Recherche d'une méthode avec application à un manuscrit du XI siècle : le lectionnaire de Lobbes, codex Bruxellensis 18018, Gand: Ėditions Story-Scientia.

Jakobi-Mirwald, Christine (2009), 'Lost in Translation. Manuscript Terminology between Languages', in Gazette du livre médiéval, 55: 1-8.

Krause, Celia / Hegel, Philipp (2018), 'Überlegungen zur quantitativen Kodikologie: Systematische und historische Perspektiven', in: Bernhart, Toni et al. (eds), Quantitative Ansätze in den Literatur- und Geisteswissenschaften. Systematische und historische Perspektiven, Berlin: de Gruyter, 335-354.

Maniaci, Marilena (1995), 'Ricette di costruzione della pagina nei manoscritti greci e latini', in Scriptorium, 49: 16-41.

*Maniaci, Marilena (1997), 'Alla fine della riga. Divisione delle parole e continuità del testo nel manoscritto bizantino', in Scriptorium, 51: 189-233.

*Maniaci, Marilena (1999a), 'L'art de ne pas couper les peaux en quatre', in Gazette du livre médiéval, 34: 1-12.

*Maniaci, Marilena (1999b), 'L’art de ne pas couper les peaux en quatre', in Gazette du livre médiéval, 34: 1-12.

*Maniaci, Marilena (2000a), 'La struttura delle Bibbie atlantiche', in Maniaci, Marilena / Orofino, Giulia (eds), Le Bibbie atlantiche. Il Libro delle Scritture tra monumentalità e rappresentazione. Catalogo della mostra, [Milano]: Centro Tibaldi, 47-60.

*Maniaci, Marilena (2000b), 'La pergamena nel manoscritto bizantino dei secoli XI e XII: caratteristiche e modalità d'uso', in Quinio. International Journal on the History and Conservation of the Book, 2: 63-92.

Maniaci, Marilena (2002a), Costruzione e gestione della pagina nel manoscritto bizantino, Cassino: Università degli studi di Cassino.

Maniaci, Marilena (2002b), '«La serva padrona». Interazioni fra testo e glossa sulla pagina del manoscritto', in Fera, Vincenzo / Ferraù, Giacomo / Rizzo, Silvia (eds), Talking to the Text. Marginalia from Papyri to Print. Proceedings of a Conference held at Erice, 26 September - 3 October 1998 , as the $12^{\text {th }}$ Course of International School for the Study of Written Records, Messina: Centro Interdipartimentale di Studi Umanistici, I, 3-35.

*Maniaci, Marilena (2004), 'Il codice greco ‘non unitario'. Tipologie e terminologia', in: Crisci, Edoardo / Pecere, Oronzo (eds), Il codice miscellaneo. Tipologie e funzioni. Atti del convegno internazionale (Cassino, 14-17 maggio 2003), Cassino: Università degli studi di Cassino, 2004 (=Segno e testo, 2), 75-107. 
*Maniaci, Marilena (2006a), 'Words within Words: Layout Strategies in some Glossed Manuscripts of the lliad', in Manuscripta, 50, 2: 241-268.

Maniaci, Marilena (2006b), 'Problemi di mise en page dei manoscritti con commento "a cornice”. L'esempio di alcuni testimoni del'lliade', in Segno e testo, 4: 211-298.

*Maniaci, Marilena (2012), 'Costruzione e gestione dello spazio scritto fra Oriente e Occidente: principi generali e soluzioni specifiche', in Scrivere e leggere nell'alto medioevo, Spoleto: Fondazione Centro italiano di studi sull'alto medioevo (Settimana di studio, 59), 473-514.

Maniaci, Marilena (2012-2013), 'Manuscript Terminology: a Plurilingual Perspective', in Manuscript Cultures, 5: 3-10.

*Maniaci, Marilena (2015), 'Ricette e canoni di impaginazione del libro medievale. Nuove osservazioni e verifiche', in Scrineum. Rivista, 10: 1-48.

Maniaci, Marilena et al. (2011), 'Table ronde. Applications actuelles de l'informatique à la paléographie : quelles méthodes pour quelles finalités ?', in Gazette du livre médiéval, 56-57: 119-130.

Maniaci, Marilena / Ornato, Ezio (1993a), 'Che fare del proprio corpus? I. Costituzione e descrizione di una popolazione di libri a fini statistici', in Gazette du livre médiéval, 22: 2737 (repr. in [Ornato, Ezio et al.] [1997], La face cachée du livre médiéval. L'histoire du livre vue par Ezio Ornato, ses amis et ses collègues. Avec une préface d'Armando Petrucci, Roma: Viella [I libri di Viella, 10], 67-75).

Maniaci, Marilena / Ornato, Ezio (1993b), 'Che fare del proprio corpus? Il. L'osservazione “sperimentale" e l'interpretazione dei risultati', in Gazette du livre médiéval, 23: 18-27 (repr. in [Ornato, Ezio et al.] [1997], La face cachée du livre médiéval. L'histoire du livre vue par Ezio Ornato, ses amis et ses collègues. Avec une préface d'Armando Petrucci, Roma: Viella [I libri di Viella, 10], 76-83).

*Muzerelle, Denis (1999), 'Le geste et son ombre : essai sur le 'rapport modulaire' des écritures', in Gazette du livre médiéval, 35: 32-45.

*Muzerelle, Denis (2012), 'L'approche analytique des schémas de réglure. D'après l'exemple des manuscrits humanistiques', in Gazette du livre médiéval, 59: 41-63.

Muzerelle, Denis (2013), 'Jeux d'angles et jeux de plume. I. Retour sur l'hypothèse du biseautage de la plume', in Gazette du livre médiéval, 60: 1-27.

*Muzerelle, Denis (2015), 'À la (re)découverte des scriptoria : l'exemple du Catalogue des manuscrits datés français', in Nievergelt, Andreas et al. (eds), Scriptorium: Wesen - Funktion - Eigenheiten. Comité international de paléographie latine, XVIII. Kolloquium, St. Gallen 11.-14. September 2013, München: Bayerische Akademie der Wissenschaften, in Komm. beim Verlag C.H. Beck (Veröffentlichungen der Kommission für die Herausgabe der mittelalterlichen Bibliothekskataloge Deutschlands und der Schweiz), 25-50.

*Muzerelle, Denis / Ornato, Ezio (2004), La terza dimensione del libro. Aspetti codicologici della pluritestualità, in Crisci, Edoardo / Pecere, Oronzo (eds), Il codice miscellaneo. Tipologie e funzioni. Atti del convegno internazionale (Cassino, 14-17 maggio 2003), Cassino: Università degli studi di Cassino, 2004 (=Segno e testo, 2), 43-74.

Ornato, Ezio (1975), 'Statistique et paléographie : peut-on utiliser le rapport modulaire dans l'expertise des écritures médiévales ?', in Scriptorium, 29: 198-234 (repr. in [Ornato, Ezio et al.] [1997], La face cachée du livre médiéval. L'histoire du livre vue par Ezio Ornato, ses amis et ses collègues. Avec une préface d'Armando Petrucci, Roma: Viella [I libri di Viella, 10], 567-605).

Ornato, Ezio (1997), 'L'histoire du livre et les méthodes quantitatives: bilan de vingt ans de recherche', in [Ornato, Ezio et al.], La face cachée du livre médiéval. L'histoire du livre vue 
par Ezio Ornato, ses amis et ses collègues. Avec une préface d'Armando Petrucci, Roma: Viella (I libri di Viella, 10), 607-679.

*Ornato, Ezio (2004), 'Un esperimento di datazione tramite le filigrane: le "lettere p” negli incunaboli dei Paesi Bassi', in Graziaplena, Rosella, with the assistance of Livesey, Mark (eds), Paper as a Medium of Cultural Heritage: Archaeology and Conservation. $26^{\text {th }}$ Congress IPH, Roma: Istituto centrale per la patologia del libro, 2004 (Addenda, 5), 225-243.

Ornato, Ezio (2010a), 'Division du travail et pratiques de composition dans l'atelier de Günther Zainer (Augsburg, 1469)', in Aquilon, Pierre / Claerr, Thierry (eds), Le berceau du livre imprimé : autour des incunables. Actes des Rencontres Marie Pellechet, 22-24 septembre 1997 et des journées d'étude des 29 et 30 septembre 2005, Turnhout: Brepols, 57-105.

Ornato, Ezio (2010b), 'La numérisation du patrimoine livresque médiéval : avancée décisive ou miroir aux alouettes ?', in Fischer, Franz et al. (eds), Kodikologie und Paläographie im digitalen Zeitalter 2 / Codicology and Palaeography in the Digital Age 2, Norderstedt: $\mathrm{BoD}$ (Schriften des Instituts für Dokumentologie und Editorik, 3), 85-115.

Ornato, Ezio (2012), 'L'évaluation quantitative des stratégies éditoriales. Problèmes méthodologiques et techniques', in Ruzzier, Chiara / Hermand, Xavier / Ornato, Ezio, Les strategies éditoriales à l'époque de incunable: le cas des anciens Pays-Bas, Turnhout: Brepols (Bibliologia, 33) 2012, $133-$ 204.

*Ornato, Ezio (2014), 'Filigranes à gogo. Observations sur le nombre et l'homogénéité des papiers employés dans les manuscrits et les incunables', in Gazette du livre médiéval, 60:54-82.

Ornato, Ezio (2020), 'The Application of Quantitative Methods to the History of the Book', in Coulson, Frank T. / Babcock, Robert G. (eds), The Oxford Handbook of Latin Palaeography, Oxford / New York: Oxford University Press, 651-668.

Ornato, Ezio et al. (1997), La face cachée du livre médiéval. L'histoire du livre vue par Ezio Ornato, ses amis et ses collègues. Avec une préface d'Armando Petrucci, Roma: Viella (I libri di Viella, 10).

Ornato, Ezio et al. (2001), La carta occidentale nel tardo medioevo. I. Problemi metodologici e aspetti qualitativi; II. Misure strumentali, tipologia e struttura delle forme, Roma - Milano: Istituto centrale per la patologia del libro - Editrice Bibliografica (Addenda, 4).

Philippart, Guy / Trigalet, Michel (2008), 'Latin Hagiography before the Ninth Century: A Synoptic View', in Davis, Jennifer R. / McCormick, Michel (eds), The Long Morning of Medieval Europe. New Directions in Early Medieval Studies, Burlington: Ashgate, 111-129.

Quanticod - CNRS (1985), 'Un programme d'étude quantitative du livre médiéval', in Gazette du livre médiéval, 6: 7-13.

Radiciotti, Paolo (1999), 'Osservazioni di un paleografo attorno alle origini ed al significato della codicologia quantitativa', in Punti critici, 1: 57-70.

*Reynhout, Lucien (2001), 'Codicologie quantitative et paradigmes scientifiques: une typologie des formules latines de colophons de manuscrits occidentaux', in Gazette du livre médiéval, 39:1-11.

Reynhout, Lucien (2006), Formules latines de colophons. I. Texte, II. Annexes, Turnhout: Brepols (Bibliologia, 25).

Ruzzier, Chiara (2010), Entre Université et Ordres mendiants: la miniaturisation de la Bible au XIII siècle. Thèse de doctorat en Histoire médiévale, sous la direction de Jean-Philippe Genet, soutenue en 2010 à l'Université de Paris 1 - Panthéon Sorbonne.

Ruzzier, Chiara (2013), 'The Miniaturisation of Bible Manuscripts in the $13^{\text {th }}$ Century. A Comparative Study', in Light, Laura / Poleg, Eyal (eds), Form and Function in the Late Medieval Bible, Leiden, Boston: Brill (Library of the Written Word, 27), 105-125.

Stokes, Peter A. (2010), 'Teaching Manuscripts in the "Digital Age”, in Fischer, Franz et al. (eds), Kodikologie und Paläographie im digitalen Zeitalter 2 / Codicology and Palaeography in the 
Digital Age 2, Norderstedt: BoD (Schriften des Instituts für Dokumentologie und Editorik, 3), 229-245.

Stokes, Peter A. (2015), 'Digital Approaches to Palaeography and Book History: Some Challenges, Present and Future', in Frontiers in Digital Humanities 2, 5: 1-3.

Stokes, Peter A. / Noël, Geoffrey (2019), 'Exon Domesday: méthodes numériques appliquées à la codicologie pour l'étude d'un manuscrit anglo-normand', in Tabularia. Les sources des mondes normands à l'heure du numérique, http://journals.openedition.org/tabularia/4118 *Trigalet, Michel (2001), 'Compter les livres hagiographiques. Aspects quantitatifs de la création et de la diffusion de la littérature hagiographique latine (II $-\mathrm{XV}^{\mathrm{e}}$ siècle)', in Gazette du livre médiéval, 38: 1-13. 